\title{
IMPACT OF COMPOST APPLICATION IN VINEYARDS ON CHANGES OF PHYSICAL PROPERTIES OF SOIL
}

\author{
Patrik Burg ${ }^{1}$, Vladimir Masan ${ }^{1}$, Alice Cizkova ${ }^{1}$, Barbora Badalikova ${ }^{2}$ \\ ${ }^{1}$ Mendel University in Brno, Czech Republic; \\ ${ }^{2}$ Research Institute for Fodder Crops, Ltd.Troubsko, Czech Republic \\ patrik.burg@mendelu.cz
}

\begin{abstract}
Organic matter is one of the key factors with a direct impact on the soil fertility. The lack of availability of organic matter and its lack in the soil represent a current pan-European problem. Organic matter in soil plays an unmistakable role in formation of soil and improvement of the physical properties, such as soil water retention, bulk density, soil aggregation capacity, water and air mode of soil, etc. This article discusses the evaluation of influence of compost and compost with Lignohumax applied in the treated strip on changes of selected physical properties of soils. The experiments started in 2017 at two experimental sites in Lednice and Velké Bílovice (Czech Republic). The physical state of the soil was determined by using "Kopecky physical cylinders", the soil structure, moisture and penetrometer resistance were evaluated as well. The obtained results show that the bulk density reduced at both sites ranged from $1.38-1.49 \mathrm{~g} \cdot \mathrm{cm}^{-3}$, the total porosity ranged from $44.09-48.25 \%$ and the water content and aeration of the soil were roughly at the same level. The structure of the soil evaluated according to the structural coefficient was found at Lednice at the beginning of the vegetation 0.71 , at the end of the vegetation, after the compost incorporation the values were higher for the variants with the prepared compost (1.38-1.44). At the site of Velké Bílovice the initial values were 0.87 and for the fertilized variants the coefficient increased to 1.99. In addition, the water conditions were better for the fertilized variants at the Lednice station and reached the level of 16.24-17.05 \% by weight, while at the site of Velké Bílovice they reached the level 19.46-23.02 \% by weight. The penetrometric resistance values did not exceed critical limits for the fertilized variants. In the framework of sustainability, viticulture will address issues related to soil fertility in the upcoming period. Greater attention therefore has to be paid to the replacement of traditional fertilizers, such as manure, by the new fertilizers in the form of compost or digestate.
\end{abstract}

Keywords: vineyard, soil, organic matter, penetrometry, soil moisture, structural coefficient.

\section{Introduction}

The organic matter in the soil has its unmistakable role in formation and improvement of its physical properties, such as soil retention capacity, bulk density, soil aggregation capacity and the soil water regime [1]. The organic matter significantly influences the development of soil edaphone and biological and chemical processes contributing to soil quality [2]. Organic matter is one of the basic factors of soil fertility. Its lack in soil is nowadays a serious problem on the European scale [3]. Specifically, in Central Europe, where the lack of organic matter is caused by lower amount of livestock farming, which has decreased by more than $50 \%$ [4]. As a result, application of organic fertilizers to arable land has been greatly reduced. If regular application of organic matter to the soil is not sufficiently ensured, its fertility decreases and it is consequently more vulnerable to wind and water erosion. Moreover, its ability to retain water is also diminished [5].

Wine-growing will further address the issue of soil fertility in the context of sustainability over the coming period. Greater attention will therefore be paid to replacing traditional fertilizers, such as manure, with new types of fertilizers in the form of compost or digestate etc. The experience so far suggests that high-quality composts are not only a source of nutrients that grapevine intakes from the soil each year, but they are also a source of organic matter [6;7]. It is known that the soil properties are one of the main factors affecting the quali-quantitative value of grapes and associated organoleptic characteristics of wine [8]. Therefore, the application of compost in a vineyard may affect the grape production and chemical composition of fruit [9].

The application of compost and its further decomposition in the soil profile can positively affect the growth of the roots as well as the above-ground parts of grapevine [10;11]. However, the optimization of effects and the effect of compost are related to determination of the necessary doses and methods of application. The existing systems use application of compost on the surface of the fertilized interlayer, followed by incorporation under the soil surface [12]. Other methods of application are tested. For example, in a pre-odorized furrow, where the applied compost reaches larger depth and where the roots are able to actively intake water and nutrients [13]. 
The aim of the paper is to evaluate the influence of compost applied in the treated strip of vineyard on the selected physical properties of soils.

\section{Materials and methods}

\section{Experimental sites}

The experiments started in 2017 at two experimental sites in Lednice and Velké Bílovice (Czech Republic). The site Lednice - is the area of mostly maize production with an altitude of $186 \mathrm{~m}$. It is classified as a very warm, dry climatic region with average annual temperature of $9{ }^{\circ} \mathrm{C}$ and with average rainfall of $500 \mathrm{~mm}$ per year. The soils here are mostly modal black soil and carbonat black soil on loess. The type of soil is medium-hard sandy without skeleton, very deep with predominantly favourable water regime. The depth of the orchard is in the range of 0.3-0.4 m. The vineyard is located on the plain. The site Velké Bílovice - is also the area of mostly maize production with an altitude of $190 \mathrm{~m}$. It is classified as a very warm, dry climatic region with average annual temperature of $9{ }^{\circ} \mathrm{C}$ and with average rainfall of $519 \mathrm{~mm}$ per year. The soils here are loamy on the loess, predominantly aluminous with a significant proportion of dusty, clay particles, moderate heavy with a depth of $0.4 \mathrm{~m}$. The vineyard is located on the plain.

\section{Experimental variants}

At each of the experimental sites, an experiment with depth application of compost and compost enriched with Lignohumax 20 in the treated strip was conducted. In the autumn of 2017, both compost variants were put in the pre-drilled furrows at a depth of $250 \mathrm{~mm}$, and then the furrows were covered back by the soil. Each of the experimental variants was $15 \mathrm{~m}$ long and was set on two replicates. Both variants the compost itself and the compost enriched with Lignohumax 20 were applied in both cases at doses of $30 \mathrm{t} \cdot \mathrm{ha}^{-1}$. Lignohumax 20 is a concentrated aqueous solution obtained by the hydrolyticoxidative decomposition of technical lignosulfonates. It is a mixture of humic and fulvic acids and their salts, while fulvic acids and their salts predominate. Another variant was a control-free compost dose. For the compost production, the biological and vegetarian waste products were used, such as bio waste from kitchen, waste from maintenance of lawns, and straw. The composting process was carried out by the composting technology in row piles. Table 1 lists the selected compost parameters applied in vineyards.

Table 1

Selected parameters of composts applied in the vineyards

\begin{tabular}{|c|c|c|c|c|c|c|c|}
\hline Compost & Nc, \% & $\begin{array}{c}\text { P-p, } \\
\mathbf{m g} \cdot \mathbf{k g}^{-1}\end{array}$ & $\begin{array}{c}\text { K-p, } \\
\text { mg.kg-1 }\end{array}$ & $\begin{array}{c}\text { Mg-p, } \\
\text { mg.kg-1 }\end{array}$ & $\begin{array}{c}\text { Dry } \\
\text { matter, \% }\end{array}$ & $\mathbf{p H}_{\mathrm{KCL}}$ & $\begin{array}{c}\mathrm{C}_{\mathrm{OX}}, \\
\%\end{array}$ \\
\hline Without Lignohumax 20 & 0.15 & 192.0 & 953.0 & 302.0 & 91.4 & 7.3 & 2.08 \\
\hline With Lignohumax 20 & 0.67 & 179.0 & 458.0 & 345.0 & 67.1 & 6.8 & 1.78 \\
\hline
\end{tabular}

Equipment and soil penetration resistance measuring methods

The initial physical state of the soil was determined in the autumn 2017, by using "Kopecky physical cylinders". Likewise, in 2018 soil samples were taken once a year at the beginning of the vegetation period, in duplicate from each experimental variants, from the depth of $0-0.10 \mathrm{~m}, 0.10-$ $0.20 \mathrm{~m}, 0.20-0.30 \mathrm{~m}$, and the following was considered: bulk density reduced, total porosity, current water and air content, maximum capillary water capacity and minimum air capacity.

In the autumn 2017, at beginning and at the end of the vegetation in 2018 the soil structure was determined by sieving dry soil on meshes with average hole openings of $0.25 ; 0.5 ; 2 ; 5 ; 10 ; 20 \mathrm{~mm}$. Samples were taken from two depths, $0-0.15$ and $0.15-0.30 \mathrm{~m}$ in three replicates. Each structural fraction was weighed separately and converted to percentages. For own calculation, the structural coefficient, which expresses the relationship between the agronomical valuable $(0.25-10 \mathrm{~mm})$ and less valuable structural elements ( $>10$ and $<0.25 \mathrm{~mm}$ ), has been calculated. A higher content of agronomic valuable structural elements means a higher numerical value of the structural coefficient $(S C)$. The structural coefficient was calculated using the equation:

$$
S C=\frac{\Sigma \text { percentage of agronomic valuables tructural elements }}{\Sigma \text { percentage of agronomic less valuable structural elements }} .
$$


The penetrometric measurements were performed by using the Eijkelkamp P1.52 digital penetrologger to the depth of $520 \mathrm{~mm}$. At the experimental sites, the measurements were twenty times performed in the treated strip at the beginning and at the end of the vegetation in 2018.

\section{Statistical analysis}

A statistical analysis was carried out using the software package "Statistica 12.0" (StatSoft Inc., Tulsa, Oklahoma, USA). Analysis of variance was conducted and the results were compared using the Tukey's multiple range test $(\alpha=0.05)$.

\section{Results and discussion}

The initial state values of the physical properties of the soil at the beginning of the measurements in the vineyard at the Lednice site corresponded to the site conditions (Table 2). As the most important parameter of the physical properties from which other characteristics are derived, is the reduced bulk density. That was the highest in 2018 in the control variant and the lowest in the Lignohumax 20 compost variant. This was seen also in other measured values, such as low porosity and low soil moisture. The maximum capillary water capacity was measured below the $36 \%$ limit for this type of soil, which means that the soil tends to dry out more quickly. However, less favourable was the measured maximum capillary capacity, which was higher than $36 \%$. It is possible that this was a reaction to a higher amount of decomposed compost from the autumn of 2017. The minimum air capacity values for the compost variant and Lignohumax 20 compost were below the $10 \%$ vol.

Physical character of soil, average values - site Lednice

\begin{tabular}{|c|c|c|c|c|c|c|c|}
\hline \multirow[t]{2}{*}{ Year } & \multirow[t]{2}{*}{ Variant } & \multirow[t]{2}{*}{$\begin{array}{c}\text { Bulk } \\
\text { density, } \\
\text { g· } \mathrm{cm}^{-3}\end{array}$} & \multirow[t]{2}{*}{ Porosity, \% } & \multicolumn{2}{|c|}{$\begin{array}{c}\text { Current volume, } \\
\% \text { volume }\end{array}$} & $\begin{array}{c}\text { Maximum } \\
\text { capillary } \\
\text { capacity }\end{array}$ & $\begin{array}{l}\text { Minimal air } \\
\text { capacity }\end{array}$ \\
\hline & & & & $\mathbf{V}$ & $\mathbf{A i r}$ & $(\% \mathrm{vc}$ & \\
\hline 2017 & Initial state & $1.38=$ & 48.25 & $21.71 \pm$ & $26.53 \pm 9.69^{a}$ & $34.74 \pm 4.19$ & 13.5 \\
\hline 2018 & & & $40.86 \pm 4.63^{\mathrm{a}}$ & & $28.27 \pm 3.34^{\mathrm{a}}$ & $30.08 \pm 7.78$ & 10.79 \\
\hline 2018 & 011 & $1.50 \pm 0.07^{\mathrm{a}}$ & $42.39 \pm 2.61^{\mathrm{a}}$ & $20.05 \pm 1.63^{\mathrm{a}}$ & $22.34 \pm 4.02^{\mathrm{a}}$ & $33.05 \pm 7.02$ & $9.34 \pm 5.13^{\mathrm{a}}$ \\
\hline 2018 & $\begin{array}{l}\text { Compost + L1 } \\
\text { gnohumax } 20\end{array}$ & $1.36 \pm 0.12^{\mathrm{a}}$ & $47.55 \pm 4.80^{\mathrm{a}}$ & $20.34 \pm 2.22^{\mathrm{a}}$ & $27.20 \pm 6.96^{\mathrm{a}}$ & $37.65 \pm 3.25$ & $9.89 \pm 2.69^{\mathrm{a}}$ \\
\hline
\end{tabular}

Legend: Data are expressed as means \pm standard deviation, different letters in the same columns represent significant difference $(P<0.05)$.

In Table 3 the physical properties of the soil in the vineyard at Velké Bílovice are evaluated. In this site the highest values of the reduced bulk density in the control variant were again found, but did not reach the limit values of $1.45 \mathrm{~g} \cdot \mathrm{cm}^{-3}$. The soil in both fertilized variants showed favourable aeration and porosity. Maximum capillary capacities were higher than those at Lednice, but the minimum air capacity values were lower.

Kirchmann [14] and Mugnai [9] state that composts can replace the reduced amount of organic matter in soils and modify the soil physicochemical properties, such as nitrogen and phosphorus concentrations, bulk density, porosity, and water-holding capacity.

Pinamonti [15] declares that the application of compost could be beneficial for soil conservation, especially in degraded soils and those susceptible to erosion, although the response to soil amendment is soil-site specific. A number of authors, such as Karhu [16] and Baronti [17], note that the addition of compost or compost-like substances to soil in vineyards positively influences the soil water holding capacity, water infiltration, soil water availability, nutrient retention, conductivity, and soil aeration.

The structure of the soil, evaluated according to the structural coefficient, was found at Lednice and Velké Bílovice at the end of vegetation period in 2017 very low, since the values were lower than 1 (Table 4). During both measurements in 2018, after the compost was added, there are noticeable increases in the values. On both sites, a significant difference was found in the values of the structural coefficient by the variants where the compost was added as well as Lignohumax 20 compost during 
the autumn 2018 measurement compared to the autumn 2017 baseline. Also Šimanský [18] states that the soil structure is a key factor of soil quality, which plays an important role in the formation of favorable physical conditions for vine growing. Also soil management and application of organic fertilizers have a significant effect on the structure coefficient. In intensively managed vineyards the values of the structural coefficient are in the treated strip at the level of 1.30-2.45 and in the interlayer between $0.60-0.90$ [19].

Table 3

Physical character of soil, average values - site Velké Bílovice

\begin{tabular}{|c|c|c|c|c|c|c|c|}
\hline \multirow{2}{*}{ Year } & \multirow{2}{*}{ Variant } & \multirow{2}{*}{$\begin{array}{c}\text { Bulk } \\
\text { density, } \\
\mathbf{g} \cdot \mathbf{c m}^{-\mathbf{3}}\end{array}$} & \multirow{2}{*}{ Porosity, \% } & \multicolumn{2}{|c|}{$\begin{array}{c}\text { Current volume, } \\
\text { \% volume }\end{array}$} & $\begin{array}{c}\text { Maximum } \\
\text { capillary } \\
\text { capacity }\end{array}$ & $\begin{array}{c}\text { Minimal air } \\
\text { capacity }\end{array}$ \\
\cline { 5 - 8 } & & & Water & Air & \multicolumn{2}{|c|}{$(\boldsymbol{\%}$ volume $)$} \\
\hline 2017 & Initial state & $1.43 \pm 0.05^{\mathrm{a}}$ & $45.56 \pm 1.93^{\mathrm{a}}$ & $22.91 \pm 1.53^{\mathrm{ab}}$ & $21.64 \pm 2.76^{\mathrm{a}}$ & $35.42 \pm 3.41^{\mathrm{a}}$ & $10.14 \pm 2.43^{\mathrm{a}}$ \\
\hline 2018 & Control & $1.24 \pm 0.17^{\mathrm{a}}$ & $52.39 \pm 6.48^{\mathrm{a}}$ & $20.45 \pm 4.85^{\mathrm{a}}$ & $31.94 \pm 11.33^{\mathrm{a}}$ & $36.56 \pm 2.60^{\mathrm{a}}$ & $15.73 \pm 3.76^{\mathrm{ab}}$ \\
\hline 2018 & Compost & $1.19 \pm 0.10^{\mathrm{a}}$ & $54.33 \pm 4.00^{\mathrm{a}}$ & $19.10 \pm 4.60^{\mathrm{a}}$ & $34.63 \pm 8.59^{\mathrm{a}}$ & $38.85 \pm 2.72^{\mathrm{a}}$ & $15.48 \pm 1.29^{\mathrm{ab}}$ \\
\hline 2018 & $\begin{array}{c}\text { Compost }+ \\
\text { Lignohuma } \\
\text { x 20 }\end{array}$ & $1.18 \pm 0.11^{\mathrm{a}}$ & $54.80 \pm 4.03^{\mathrm{a}}$ & $34.61 \pm 6.03^{\mathrm{b}}$ & $34.61 \pm 6.03^{\mathrm{a}}$ & $37.79 \pm 3.73^{\mathrm{a}}$ & $17.01 \pm 2.42^{\mathrm{b}}$ \\
\hline
\end{tabular}

Legend: Data are expressed as means \pm standard deviation, different letters in the same columns represent significant difference $(P<0.05)$.

Table 4

Average values of the structural coefficient

\begin{tabular}{|c|c|c|c|c|}
\hline \multirow{2}{*}{$\begin{array}{c}\text { Date of } \\
\text { measurement }\end{array}$} & \multirow{2}{*}{$\begin{array}{c}\text { Year of } \\
\text { measurement }\end{array}$} & \multirow{2}{*}{ Variant } & \multicolumn{2}{|c|}{ Structural coefficient } \\
\hline & & & Site of Lednice & Site of Velké Bílovice \\
\hline Autumn & 2017 & Original state & $0.60 \pm 0.21^{\mathrm{a}}$ & $0.87 \pm 0.17^{\mathrm{a}}$ \\
\hline Spring & 2018 & Control & $0.87 \pm 0.08^{\mathrm{ab}}$ & $1.20 \pm 0.01^{\mathrm{ab}}$ \\
\hline Spring & 2018 & Compost & $1.55 \pm 0.03^{\mathrm{bcd}}$ & $1.52 \pm 0.37^{\mathrm{ab}}$ \\
\hline Spring & 2018 & $\begin{array}{c}\text { Compost + Lignohum } \\
\text { ax } 20\end{array}$ & $1.59 \pm 0.05^{\mathrm{cd}}$ & $1.84 \pm 0.25^{\mathrm{ab}}$ \\
\hline Autumn & 2018 & Control & $1.93 \pm 0.02^{\mathrm{de}}$ & $2.22 \pm 0.62^{\mathrm{bc}}$ \\
\hline Autumn & 2018 & Compost & $2.53 \pm 0.23^{\mathrm{e}}$ & $3.04 \pm 0.35^{\mathrm{de}}$ \\
\hline Autumn & 2018 & $\begin{array}{c}\text { Compost + Lignohum } \\
\text { ax } 20\end{array}$ & $2.59 \pm 0.04^{\mathrm{e}}$ & $3.53 \pm 0.10^{\mathrm{e}}$ \\
\hline
\end{tabular}

Legend: Data are expressed as means \pm standard deviation, different letters in the same columns represent significant difference $(P<0.05)$.

The soil moisture measurements show that higher moisture contents were achieved in the variants with application of compost and compost enriched with Lignohumax 20 compared to the control variant (Table 5) at both sites. Pinamonti [15] states that the benefits of applying compost are mainly related to an indirect effect on the soil moisture levels, it reduces plant stress, and the risk of crop failure.

Table 5

Average values of soil moisture

\begin{tabular}{|c|c|c|c|}
\hline \multirow{2}{*}{$\begin{array}{c}\text { Year of } \\
\text { measurement }\end{array}$} & \multirow[b]{2}{*}{ Variant } & \multicolumn{2}{|c|}{ Soil moisture, \% volume } \\
\hline & & $\begin{array}{c}\text { Site of } \\
\text { Lednice }\end{array}$ & $\begin{array}{c}\text { Site of } \\
\text { Velké Bílovice }\end{array}$ \\
\hline 2017 & Initial state & $15.45 \pm 0.55^{b}$ & $15.04 \pm 1.20^{\mathrm{a}}$ \\
\hline 2018 & Control & $12.85 \pm 1.14^{\mathrm{ab}}$ & $16.64 \pm 1.92^{\mathrm{ab}}$ \\
\hline 2018 & Compost & $14.48 \pm 1.39^{\mathrm{ab}}$ & $21.37 \pm 2.78^{\mathrm{bc}}$ \\
\hline 2018 & $\begin{array}{c}\text { Compost + Ligno } \\
\text { humax } 20\end{array}$ & $16.87 \pm 0.62^{\mathrm{c}}$ & $23.02 \pm 1.91^{\mathrm{c}}$ \\
\hline
\end{tabular}

Legend: Data are expressed as means \pm standard deviation, different letters in the same columns represent significant difference $(P<0.05)$.

At the beginning and at the end of the vegetation in 2018 at both experimental sites the penetrometer measurements were carried out by using the hand penetrometer at a depth of $520 \mathrm{~mm}$. 
The resulting values of the penetrometric resistance of soil (MPa) from the spring and autumn measurements are shown in Figure 1 and 2, and compared with the critical values reported by Lhotský [20].

From Figure 1 it is clear that the soil of Lednice shows relatively low soil compaction values during the spring and autumn measurements, with a maximum measured of $3.3 \mathrm{MPa}$. The measurements made indicate that the highest values of the soil penetrometric resistance are shown by the control variant (without fertilization) during both, the spring as well as the autumn measurements. In overall, the highest values of the soil penetrometric resistance is shown by the variant with application of simple compost.

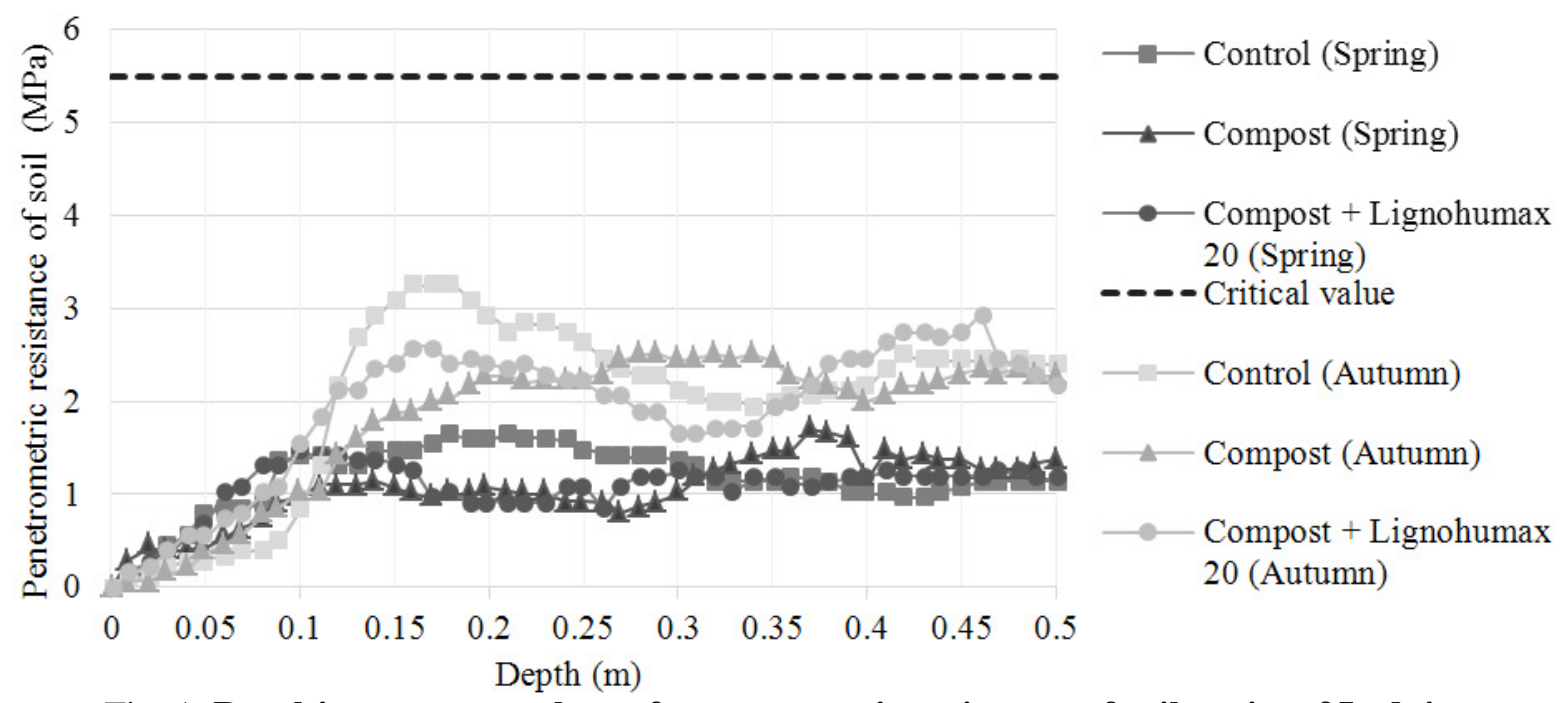

Fig. 1. Resulting average values of penetrometric resistence of soil at site of Lednice

Figure 2 shows that during spring measurements, soil compaction was the highest in the nonfertilized control variant. The lowest values of the penetrometric resistance of the soil were shown by the variant fertilized with Lignohumax 20 . The autumn values clearly support the significant increase of soil compaction during vegetation, which is linked to the repeated use of mechanization. In the autumn measurement, the measured values of the penetrometric resistance of the soil were the highest in the non-fertilized control variant (at a depth of $0.43 \mathrm{~m}$ the critical value was exceeded), and the lowest in the variant fertilized with humates.

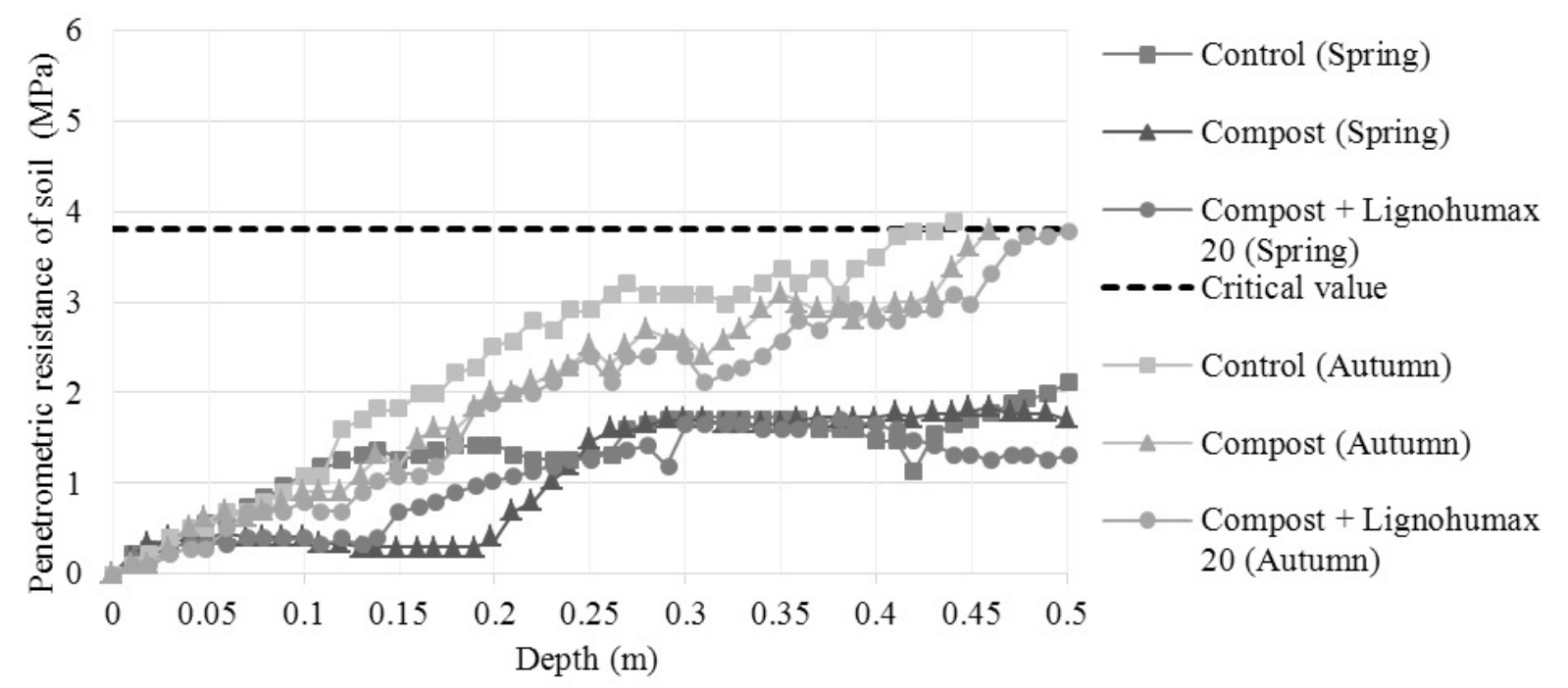

Fig. 2. Resulting average values of penetrometric resistence of soil at site of Velké Bílovice 


\section{Conclusions}

1. From the results obtained so far the positive influence of compost and compost with Lignohumax 20 is recorded on the assessed physical parameters of soil at both sites, namely, bulk density, porosity, current water and air content, maximum capillary capacity and minimal air capacity.

2. The applied compost and compost with Lignohumax 20 positively affect the increase in the structural coefficient from the basic measurements from 0.60-1.30 until 2.59-3.53.

3. For both fertilized variants higher soil moisture was measured compared to the non-fertilized control variant, while the difference is approximately $28-31 \%$.

4. When measuring the penterometric resistance of the soil, both fertilized variants show lower compaction of soil at both experimental sites, while not exceeding the critical limit.

\section{Acknowledgements}

This paper was finalized and supported by the project TH02030467 "Development and verification of machine for in-depth installation of organic stuff to soil in vineyards and orchards (2017-2020)".

\section{References}

[1] Borselli L., Pellegrini S., Torri D. etc. (2002): Tillage erosion and land levelling: evidences in Tuscany (Italy). Proceedings of International Congress of the European Society for Soil Conservation, March 28 - April 1, 2000. Valencia, Spain, pp.1341-1350.

[2] Diacono M., Montemurro F. Compost da residui organici per l'agricoltura biologica. Agrifoglio, vol. 16, 2006, pp. 18-19.

[3] Pinamonti F., Sicher L. Compost Utilization in Fruit Production Systems. In: P.J. Stoffella and B.A. Kahn. Compost Utilization in Horticultural Cropping Systems. New York: Lewis Publishers, 2001. pp.177-200.

[4] Budňaková M. 2015. Situační a výhledová zpráva, Réva vinná a víno (Situation and Outlook Report, Grapevine and wine). Praha: Ministerstvo zemědělství Česke republiky, 2015. 81 p.(In Czech).

[5] Badalíková B., Marešová K. (2009): Zlepšení infiltrace půdy po aplikaci kompostů z biologicky rozložitelných odpadů (Improving soil infiltration after application of composts from biodegradable waste). Mezinárodní vědecká konference, využitie výsledkov výskumu k zlepšeniu vzt’ahu pol'nohospodárskej činnosti a životného prostredia (International scientific conference, use of research results to improve the relationship of agricultural activity and environment), Mužla, Slovakia, 2009, pp.1-9.(In Czech).

[6] Biala J. The use of recycled organics compost in viticulture - a review of the international literature and experience. Proceedings of the 6th International Congress on Organic Viticulture, August 25-26, 2000, Basel, Switzerland, pp.130-134.

[7] Hůla J. Úprava fyzikálních vlastností půdy a retenční schopnosti půdy zapravením kompostů z odpadní biomasy: uplatněná certifikovaná metodika (Modification of soil physical properties and soil retention capability by incorporation of compost from waste biomass: Certified methodology applied). Praha: Výzkumný ústav zemědělské techniky, 2012. 29 p. (In Czech).

[8] Korboulewsky N., Robles C.,Garzino S. Effects of sewage sludge compost on volatile organic compounds of wine from Vitis vinifera cv. red Grenache. Am. J. Enol. Vitic., vol. 55, 2004, pp. $412-416$.

[9] Mugnai S., Masi E., Azzarello E. etc.Influence of Long-Term Application of Green Waste Compost on Soil Characteristics and Growth, Yield and Quality of Grape (Vitisvinifera L.), Compost Science \& Utilization, vol. 20, 2012, pp. 29-33.

[10] Concheri G., Nardi S., Reniero F. etc. The effects of humic substances within the Ah horizon of a Calcic Luvisol on morphological changes related to invertase and peroxidase activities in wheat roots. Plant Soil,vol. 179, 1996, pp. 65-72.

[11] Nardi S., Pizzeghello D., Muscolo A.etc. Physiological effects of humic substances on higher plants. Soil Biol. Biochem.,vol. 34, 2002, pp. 1527-1536. 
[12]Burg P., Zemánek P., Badalíková B.etc. Degradační procesy půd ve vinicích a možnosti jejich nápravy (Soil compaction in vineyards and possibilities of their remedy). Folia Universitatis Agriculturae et Silviculturae Mendelianae Brunensis: Mendelova univerzita v Brně, 2016, No. 2. (In Czech).

[13] Gaiotti F., Marcuzzo P., Belfiore N. etc. Influence of compost addition on soil properties, root growth and vine performances of Vitis vinifera cv Cabernet sauvignon, Scientia Horticulturae,vol. 225, 2017, pp. 88-95.

[14] Kirchmann H. Relationship between soil organic matter and micropores in a long-term experiment at Ultuna, Sweden. J. Plant Nutr. Soil Sci., vol. 162, 1999, pp. 493-498.

[15] Pinamonti F. Compost mulch effects on soil fertility, nutritional status and performance of grapevine. Nutr. Cycl. Agroecosyst., vol. 51, 19981 pp. 239-248.

[16] Karhu K., Mattila T., Bergström I. etc. Biochar addition to agriculturalsoil increased CH4 uptake and water holding capacity - results from a short-termpilot field study. Agric. Ecosyst. Environ., vol. 140, 2011, pp. 309-313.

[17] Baronti S., Vaccari F.P., Miglietta F. etc. Impact of biochar application on plant water rela-tions in Vitis vinifera (L.). Eur. J. Agron., vol. 53, 2014, pp. 38-44.

[18] Šimanský V. Assessment of soil structure under monoculture of vines. Roczniki gleboznawcze soil science annual,vol. 63, 2012, pp. 42-45.

[19] Tobiašová $E$. The effect of organic matter on the structure of soils of different land uses. Soil \& Tillage Res., vol. 114, 2011, pp. 183-192.

[20]Lhotský J. Zhutňování půd a opatření proti němu (Soil compaction and measures against it). Praha: Ústav zemědělských a potravinářských informací, 2000, 61 p. (In Czech). 